DOI: $10.19195 / 0137-1134.114 .14$

\author{
JERZY SUPERNAT \\ Uniwersytet Wrocławski \\ jerzy.supernat@uwr.edu.pl
}

\title{
Z ZAGADNIEŃ KOMPARATYSTYKI PRAWNICZEJ
}

\begin{abstract}
Abstrakt: Komparatystyka prawnicza zawsze była istotna w stanowieniu i stosowaniu prawa, ale w sytuacji kształtowania się ponadpaństwowych przestrzeni prawnych jest niezastąpiona. W tych okolicznościach opracowanie poświęcone jest czterem wybranym zagadnieniom komparatystyki prawniczej: badaniu prawa i badaniu refleksji naukowej o nim, poszukiwaniu podobieństw i różnic, badaniom pragmatycznym w europejskiej przestrzeni administracyjno-prawnej oraz komparatystyce prawniczej nominalnej.
\end{abstract}

Słowa kluczowe: komparatystyka, prawo, komparatystyka prawnicza

W dorobku Jubilata Profesora Leona Kieresa widoczny i ważny jest nurt komparatystyczny, co zachęca do dokonania identyfikacji i omówienia wybranych podstawowych zagadnień komparatystyki prawniczej. Nurt badań komparatystycznych jest dzisiaj krytyczny dla zrozumienia między innymi integracji europejskiej, w tym w mocno dzisiaj rysującym się wymiarze integracji administracyjnej, a w wymiarze praktycznym — do jej przeprowadzenia ${ }^{1}$. A dodać należy, że kwestia integracji europejskiej była wielokrotnie podejmowana przez Jubilata, co stanowi dodatkowy argument na rzecz dokonanego wyboru treści ofiarowanego Mu opracowania. Stałym zaś argumentem na rzecz tego wyboru jest to, że mimo rosnącego znaczenia i zastosowania komparatystyki prawniczej wielu współczesnych przedstawicieli prawa porównawczego wskazuje na niespójne wyjaśnienie jej celu i metod ${ }^{2}$.

1 Z. Brodecki celnie podkreśla, że badania porównawcze są ,konieczne w trakcie tworzenia prawa krajowego okresu transformacji ustrojowej oraz tworzenia lub stosowania prawa ponadnarodowego i międzynarodowego", idem, Metodologia regulae iuris, [w:] Z. Brodecki, M. Konopacka, A. Brodecka-Chamera, Komparatystyka kultur prawnych, Warszawa 2010, s. 19. Z pewną emfazą pisze: „Przenoszenie punktu ciężkości polityki prawa z prawa krajowego na prawo ponadnarodowe i międzynarodowe zmusza metodologów do dokonania heweliuszowskiego przewrotu w komparatystyce prawniczej", ibidem.

2 Zob. na przykład H.P. Glenn, Legal Traditions of the World. Sustainable Diversity in Law, Oxford 2010; Comparative Law in the 21st Century, red. A. Harding, E. Örücü, London 2002; E. Örücü, 


\section{BADANIE PRAWA I BADANIE REFLEKSJI NAUKOWEJ O NIM}

Rozpocznijmy od zwrócenia uwagi na to, co jest fundamentalne dla komparatystyki prawniczej, a mianowicie na rozróżnienie między badaniem prawa a badaniem refleksji naukowej o nim. W konkretnym przypadku między badaniem prawa administracyjnego i nauki prawa administracyjnego. Ten właśnie przypadek stał się punktem wyjścia pionierskiej pracy Franciszka Longchamps ${ }^{3}$, który zbadał w sposób porównawczy i omówił główne kierunki w nauce prawa administracyjnego w siedmiu państwach Europy Zachodniej ${ }^{4}$. Ważne, że w argumentacji na rzecz dokonanego wyboru autor wskazał na znaczenie administracji i prawa administracyjnego dla jakości życia społeczeństw i poszczególnych ludzi, co notabene powoduje, że „i administracja, i prawo administracyjne są zjawiskami dla dzisiejszego człowieka dość bliskim, patrząc na rzecz w całości życia prawnego"5. Jednocześnie zauważył, że „nauka prawa administracyjnego jest mało znana

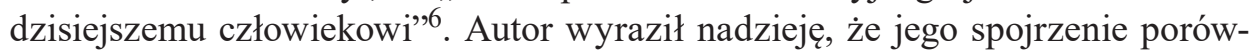
nawcze na kierunki w nauce prawa administracyjnego Europy Zachodniej pozwoli zobaczyć, że nauka ta potrafi „ciekawie i trafnie” opisywać i analizować swój przedmiot, „otwierać szerokie horyzonty badawcze i dawać impulsy dla bardziej ogólnych refleksji”, co spowoduje szersze zainteresowanie tą nauką także w Polsce? $^{7}$. Same badania porównawcze wymagały decyzji dotyczących problemów delimitacji, czyli de facto wyznaczenia pola badań.

Najpierw problemu dotyczącego tego, czy badać tylko naukę prawa administracyjnego, czy także inne nauki, które interesują różne tematy i wątki w prawie

Developing Comparative Law, [w:] Comparative Law. A Handbook, red. D. Nelken, E. Örücü, Portland 2007, s. 43 i n.

${ }^{3}$ F. Longchamps de Berier, Współczesne kierunki w nauce prawa administracyjnego na Zachodzie Europy, Wrocław 2001. Dzieło to po raz pierwszy zostało wydane w 1968 r., ale — jak piszą autorzy wstępu do drugiego wydania (A. Błaś, J. Boć, A. Chełmoński, J. Jeżewski i K. Nowacki) „nic bądź niewiele straciło na aktualności”, ibidem, s. V. We wspomnieniu o F. Longchamps de Berier autorstwa J. Jeżewskiego o pracy tej czytamy: „Jest to jedyna tego rodzaju książka w piśmiennictwie europejskim; w ujęciu najogólniejszym jej wartość polega na ukazaniu precyzyjnej i kompletnej metody porównawczej badania myśli prawnej oraz jej zastosowania w analizie założeń, motywów, uwarunkowań, które od 1945 r. wywierały wyraźny (a często decydujący) wpływ na teoretyczną konstrukcję nauki prawa administracyjnego w Europie", idem, Franciszek Longchamps de Berier (1912-1969), [w:] Pamięci zmarlych Profesorów i Docentów Wydziału Prawa, Administracji i Ekonomii Uniwersytetu Wrocławskiego 1945-2010, red. L. Lehmann, M. Maciejewski, Wrocław 2010, s. 188. Dodać też należy, że prace z komparatystki myśli prawnej do dzisiaj należą do rzadkości.

${ }^{4}$ Przed ukazaniem się dzieła F. Longchamps de Beriera pracy porównawczej dotyczącej nauki prawa administracyjnego w państwach zachodnich w Polsce nie było. Krótko przed jej wydaniem ukazała się książka J. Starościaka Wprowadzenie do prawa administracyjnego europejskich państw socjalistycznych, Warszawa 1968, omawiająca w pierwszym rozdziale podstawowe kierunki i tematy w nauce prawa administracyjnego tych państw.

${ }^{5}$ F. Longchamps de Berier, op. cit., s. 3-4.

6 Ibidem, s. 4.

7 Ibidem. 
administracyjnym, żeby wskazać dla przykładu naukę prawa konstytucyjnego, teorię i filozofię prawa, nauki polityczne i naukę ekonomii. Chodzi o to, aby „nie pominąć ciekawej jakiejś myśli o prawie administracyjnym, tylko dlatego, że zo-

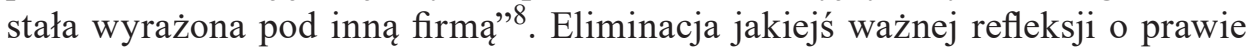
administracyjnym nie powinna być także następstwem przyjęcia określonego programu nauczania tego prawa czy „organizacja katedr uniwersyteckich”9. Odpowiadając twierdząco na zadane pytanie, F. Longchamps nie ukrywał, że wytyczenie tutaj granicy nie jest łatwe i wiele miejsc pozostaje wątpliwych. Szczególną trudność w wyznaczeniu pola badania rodzi rozgraniczenie między nauką prawa administracyjnego a nauką administracji, którą F. Longchamps rozumiał jako: „opisowe i porównawcze badanie administracji publicznej jako faktu społecznego oraz próby jej teoretyzacji i ustalenia podstaw dla dobrej administracji”" ${ }^{\prime 10}$. Innymi słowy chodzi o trudną kwestię związków między dwiema sferami - normatywną i faktyczną. Trudność wynika $\mathrm{z}$ tego, że bardzo wielu prawników daje w swych pracach ,wartościowe wątki dla badania [...] rzeczywistej administracji i dla zarysów jej teorii" ${ }^{11}$, a nadto poznanie prawa administracyjnego jest także poznaniem w jakimś stopniu czy zakresie rzeczywistej administracji ${ }^{12}$. Stąd w wyważonej konkluzji autor stwierdza, że z zasady jego zamiarem nie jest badanie przejawów nauki administracji, ale jednocześnie zauważa: „[j]eśli jednak dzisiejsza nauka prawa obejmuje pewne regiony, przed którymi do niedawna się wstrzymywała dlatego, że należą one do nauki administracji, nie omieszkam tego przedstawić"13.

Kolejne problemy metodologiczne i kompozycyjne (strukturalne) związane z wytyczeniem pola badań dotyczyły tego, czy najpierw określić główne kierunki w nauce prawa administracyjnego, a potem dopiero dokonać relacji ze stanu nauki, czy odwrotnie. Aby uniknąć zarzutu aprioryzmu, autor zdecydował się rozpo-

8 Ibidem, s. 5.

9 Ibidem. Stanowisko takie po części wyjaśnia przyjęcie określonej struktury Instytutu Nauk Administracyjnych, utworzonego z inicjatywy F. Longchamps w 1969 r., w którego skład, oprócz Zakładu Prawa Administracyjnego, wchodziły jeszcze: Zakład Nauki Administracji, Zakłada Prawa Finansowego i Nauki o Finansach, Zakład Statystyki i Badań Operacyjnych oraz Zakład Zarządzania Gospodarką Narodową (od 1972 r.).

10 Ibidem.

11 Ibidem. Do prawników tych należał sam F. Longchamps. Lista prawników podejmujących się badania administracji publicznej nie tylko jako faktu prawnego, lecz także faktu społecznego jest w Polsce wyjątkowo długa, między innymi: A. Błaś, W. Dawidowicz, J. Jagielski, J. Jeżewski, Z. Kmieciak, E. Knosala, T. Kuta, Z. Leoński, J. Łukasiewicz, J. Służewski, J. Starościak, J. Szreniawski i J. Zimmermann.

$12 \mathrm{Na}$ temat związków nauki prawa administracyjnego z nauką administracji zob. szeroko J. Jeżewski, Administracja publiczna jako przedmiot badań, [w:] A. Błaś, J. Boć (red.), J. Jeżewski, Nauka administracji, Wrocław 2013, s. 354 n. Autor wskazuje między innymi na ,pojęcia zawarte w podręcznikach prawa administracyjnego, dobrze tam zadomowione, które mogą służyć zarówno kwalifikacji konstrukcji zawartych w przepisach prawnych, jak też kwalifikacji rozlicznych przejawów praktyki ustrojowej, daleko wychodzących poza determinację ściśle prawną", ibidem, s. 365.

13 F. Longchamps de Berier, op. cit., s. 6. 
cząć od przeglądu stanu nauki ${ }^{14}$. Stanowisko takie przyniosło pytanie o porządek dokonania przeglądu. Wskazując, że doktryna prawa „rozwija się w obrębie jednej organizacji państwowej, dotyczy jednego systemu prawnego, używa jednego języka"15, autor zdecydował się na ekspozycję według krajów, wybierając spośród szesnastu państw zaliczanych wtedy konwencjonalnie do Europy Zachodniej siedem najważniejszych i najbardziej znaczących z punktu widzenia przedmiotu badań: Francję, Belgię, zachodnie Niemcy, Austrię, Szwajcarię, Włochy i Anglię, wyrażając żal z pominięcia krajów skandynawskich.

Z kolei aby zapewnić porównywalność badanych zjawisk i zebrać materiał do wniosków i uogólnień, F. Longchamps, w sytuacji braku ustalonych wzorów co do porównawczego badania myśli prawnej, zdecydował się ,nieco arbitralnie” na badanie najpierw tematów, którymi zajmuje się dany autor, czyli ,tematów pierwszego stopnia”, a następnie sposobów, w jaki nimi się zajmuje, które nazywa „tematami drugiego stopnia" i które stanowią właściwy przedmiot jego badania ${ }^{16}$. Tematy pierwszego stopnia musiały być odpowiednio szerokie i takie same dla każdego państwa, aby zagwarantować płaszczyznę porównywania różnych i nawet rozbieżnych zjawisk naukowych. Po wielu ,,przymiarkach i wahaniach” F. Longchamps zdecydował się na sześć tematów pierwszego stopnia dla każdego państwa: zakres i system prawa administracyjnego, źródła prawa administracyjnego, struktura prawna administracji, sytuacja prawna człowieka wobec administracji, kontrola prawna nad administracją oraz wartość prawa administracyjnego i nauki prawa administracyjnego. Poglądy na te tematy dały następującą listę tematów drugiego stopnia dla każdego państwa: jak autorzy widzą zakres i system prawa administracyjnego, jak źródła prawa administracyjnego, jak strukturę prawną administracji, jak sytuację prawną człowieka wobec administracji, jak kontrolę prawną nad administracją oraz jak widzą wartość prawa administracyjnego i nauki prawa administracyjnego ${ }^{17}$. W przekonaniu F. Longchamps te sześć tematów razem pozwala uchwycić najbardziej znamienne zjawiska naukowe w każdym z wybranych do zbadania państw i je porównać. Wracając do punktu wyjścia, a mianowicie rozróżnienia między badaniem prawa i badaniem refleksji naukowej o nim, należy na koniec tego fragmentu zauważyć, że F. Longchamps wyłączył z badanych prac (publikacji) ${ }^{18}$ wszystkie

14 Zob. ibidem.

15 Ibidem, s. 7. Patrząc na tworzenie i rozwój organizacji ponadpaństwowych, pogląd taki można dzisiaj kwestionować. Odnośnie do języka (języków) administracji publicznej we współczesnej Europie zob. E. Ongaro, S. von Thiel, Languages and Public Administration in Europe, [w:] The Palgrave Handbook of Public Administration and Management in Europe, t. 1, red. E. Ongaro, S. von Thiel, London 2018, s. 61 n.

16 Zob. F. Longchamps de Berier, op. cit., s. 8-9.

17 Zob. ibidem, s. 9. Można wyrazić żal, że wśród wybranych tematów pierwszego stopnia nie znalazł się akt administracyjny.

18 Autor sformułował ciekawą myśl odnośnie do badanego materiału: „na prace dotyczące poszczególnych działów prawa, na naukę prawa (w potocznym sensie), patrzy się zazwyczaj jako na »literaturę przedmiotu«. Tu ma być ona... przedmiotem literatury", ibidem, s. 12. 
prace porównawcze, które dotyczą prawa administracyjnego. Zadecydowały o tym dwa względy: ograniczona objętość jego pracy oraz swoistość tych prac porównawczych, sprawiająca, że zasługują one na osobne studium. Jednocześnie wyraźnie powiedział, że „obraz administratywistyki zachodnioeuropejskiej [...] wymaga tego istotnego uzupełnienia" 19 . Obraz ten w postaci głównych kierunków w nauce prawa administracyjnego na zachodzie Europy został zawarty w ostatnim rozdziale dzieła F. Longchamps ${ }^{20}$, do którego zainteresowanego nim czytelnika wypada odesłać, jako że na jego omówienie nie pozwala z kolei ograniczona objętość tego tekstu.

\section{POSZUKIWANIE PODOBIEŃSTW I RÓŻNIC}

Komparatystykę prawniczą zdaje się charakteryzować, przynajmniej do niedawna, pewne epistemologiczne nachylenie w postaci dawania pierwszeństwa podobieństwom przed różnicami oraz przyjmowania bardziej lub mniej wyraźnie, że pożądane jest, aby systemy prawne stawały się zbieżne z jakimś modelem postrzeganej najlepszej praktyki. Opis badań, przeprowadzonych ze świadomością tych zagrożeń i dążeniem do ich uniknięcia, zawiera praca z zakresu porównawczego prawa konstytucyjnego An Inquiry into the Existence of Global Values. Through the Lens of Comparative Constitutional Law ${ }^{21}$, która $\mathrm{z}$ tego powodu zasługuje na bliższą uwagę.

W nauce porównawczego prawa konstytucyjnego pozycję dominującą zdobyły cztery różne podejścia do badań komparatystycznych ${ }^{22}$. Podejście najbardziej powszechne polega na badaniu jednego kraju, który z założenia jest krajem innym niż ten, w którym autor mieszka. Następnie wybrana jurysdykcja jest badana z punktu widzenia własnego systemu konstytucyjnego autora. Bardziej ekspansywną postacią nauki porównawczego prawa konstytucyjnego jest podejście drugie, które polega na poszukiwaniu lepszego rozwiązania dla określonej krajowej jurysdykcji, przez badanie rozwiązań przyjętych $\mathrm{w}$ innych krajach z rozwiniętymi systemami konstytucyjnymi w celu ich naśladowania. Podejście trzecie, które w istocie jest odmianą drugiego, dąży do uchwycenia i zbadania podobieństwa krajowych jurysdykcji konstytucyjnych, co daje podstawę do twierdzenia o znalezieniu jakiejś formy uniwersalnego dyskursu konstytucyjnego. Podejście to znajduje wsparcie w sądowym (trybunalskim) horyzontalnym korzystaniu z idei konstytucyjnych innych państw, sugerującym rozwój międzynarodowego dyskursu konstytucyjne-

19 Ibidem, s. 11.

20 Ibidem, s. 219 n.

21 An Inquiry into the Existence of Global Values. Through the Lens of Comparative Constitutional Law, red. D. Davis, A. Richter, C. Saunders, Oxford 2015.

22 Zob. D. Davis, A. Richter, C. Saunders, Introduction, [w:] An Inquiry into the Existence of Global Values, s. 3 n. 
go, a nawet konstytucyjną konwergencję ${ }^{23}$. Wreszcie czwarte możliwe podejście do porównawczego prawa konstytucyjnego oparte jest na przekonaniu, że dobra teoria wymaga wyjaśniających pojęć, a także zaproponowania przyczynowego wyjaśnienia obserwowanych zjawisk z wykorzystaniem metod i technik nauk społecznych ${ }^{24}$. W tym przypadku budowa teorii przez inferencję przyczynową dąży do socjologicznego wyjaśnienia poszczególnych wyborów konstytucyjnych dokonanych w różnych krajach.

Badania opisane w pracy An Inquiry into the Existence of Global Values. Through the Lens of Comparative Constitutional Law oparte są zasadniczo na podejściu trzecim, jako że wychodzą z założenia, iż istnieje pewien stopień konwergencji między różnymi dokumentami konstytucyjnymi, przynajmniej na poziomie wartości fundamentalnych ${ }^{25}$. Jednocześnie badania te zostały świadomie zaprojektowane tak, aby zbadać różnice między różnymi porządkami konstytucyjnymi, zarówno z punktu widzenia sposobu rozwoju jurysprudencji przez sądy konstytucyjne ${ }^{26}$, jak i z punktu widzenia form, w jakich konstytucje funkcjonują w poszczególnych krajach. Jeżeli chodzi o wyniki, jakie przyniosły te badania, to zwięźle można powiedzieć, że nie pozwalają one stwierdzić jednoznacznie istnienia konwergencji w badanym polu po części dlatego, że przyjęty sposób ujmowania wartości nie pozwala na ich obiektywne zdefiniowanie ${ }^{27}$. Przy czym, niezależnie od stwierdzonych podobieństw między wartościami leżącymi u podstaw

$23 \mathrm{Na}$ temat administracyjnej konwergencji w europejskiej przestrzeni prawnej zob. między innymi M.W. Bauer, J. Trondal, The Administrative System of the European Union, [w:] The Palgrave Handbook of the European Administrative System, red. M.W. Bauer, J. Trondal, Basingstoke 2015, s. 1 n.; oraz J. Trondal, B.G. Peters, A Conceptual Account of the European Administrative Space, [w:] The Palgrave Handbookof the European Administrative System, s. 79 n.

24 Więcej zob. The Migration of Constitutional Ideas, red. S. Choudhry, Cambridge 2006.

25 Przekonanie o tej konwergencji ma mocne podstawy w postaci przynajmniej trzech zjawisk: korzystania w powojennych konstytucjach z rozwiązań zawartych $\mathrm{w}$ innych konstytucjach, inkorporacji w konstytucjach rozwiązań służących ochronie praw człowieka oraz transnarodowego dialogu sędziowskiego (globalizacji sędziowskiej), dotyczącego kwestii konstytucyjnych, a zwłaszcza ochrony praw człowieka.

${ }^{26}$ Notabene o jurysprudencji polskiego sądu konstytucyjnego w odniesieniu do wartości sprawności administracji przykładowo pisze L. Kieres, Sprawna administracja w orzecznictwie Trybunału Konstytucyjnego, [w:] Administracja publiczna pod rzadami prawa. Księga pamiatkowa z okazji 70-lecia urodzin prof. zw. dra hab. Adama Błasia, red. J. Korczak, Wrocław 2016, s. 193 n. Zob. też idem, Europejska Karta Samorządu Terytorialnego w orzecznictwie Trybunału Konstytucyjnego, „Ruch Prawniczy, Ekonomiczny i Socjologiczny” 2015, nr 3, s. 79 n. Autor pisze między innymi o wartościach szczególnych, uznawanych za przejaw faktycznej decentralizacji, a wywodzonych przez Trybunał Konstytucyjny z Karty, zob. ibidem, s. 85.

$27 \mathrm{~W}$ przedmiotowych badaniach przyjęto następującą roboczą definicję wartości: ,etyczny imperatyw sformułowany na wysokim poziomie abstrakcji i posiadający właściwość celu ostatecznego (the quality of an ultimate goal)", D. Davis, A. Richter, C. Saunders, op. cit., s. 11. Wartości w tym rozumieniu różnią się od praw (rights), które istnieją po to, aby służyć poszczególnym wartościom i wspierać je, chociaż jest tak, że praktycznie każda dyskusja o wartościach w systemie prawnym ma miejsce w kontekście praw. 
poszczególnych systemów konstytucyjnych, badania wykazały istnienie wielu różnych sposobów manifestowania przez systemy konstytucyjne jednej wartości, a także wielu różnych sposobów rozumienia jednej wartości (wynikających z odrębności narodowych historii i tradycji prawnych ${ }^{28}$ ). Wynika z tego, że mimo tekstowych i koncepcyjnych podobieństw konstytucji istnieją między nimi znaczące rozbieżności, czasami ujawniane w jurysprudencji o znaczącej złożoności. To w istocie kierowało badania ku politycznym i etycznym podstawom, przesadzającym o rozwoju konstytucyjnych fundamentów w badanych krajach, a były to: Afryka Południowa, Australia, Brazylia, Chiny, Finlandia, Francja, Indie, Iran, Izrael, Japonia, Kanada, Niemcy, Stany Zjednoczone, Wenezuela i Zjednoczone Królestwo. Autorzy z każdego z tych krajów zostali poproszeni o trzy rzeczy: 1. dokonanie przeglądu krajowej konstytucji (the country's bill of rights, constitution) i/lub podstawowych spraw sądowych, w celu ustalenia, czy każda wartość z listy wartości przewidzianych do zbadania została wyraźnie (lub nie) sformułowana; 2. wypowiedzenie się odnośnie do hierarchii wśród wartości (comment on the prioritisation of values); 3 . wypowiedzenie się odnośnie do zgodności czy odpowiedniości (congruence), czyli zakresu, w jakim aspirujące wartości są (lub nie) ,przestrzegane” $\mathrm{w}$ danym kraju (the extent to which the aspirant values are or are not ,lived" in that country) ${ }^{29}$. I na koniec jeszcze lista badanych wartości, aspirujących do statusu wartości globalnych. Gwoli uniknięcia translatorskich przekłamań przy toczmy je w języku badań: love ${ }^{30}$, truthfulness, fairness/justice, freedom/liberty/independence, unity/fraternity/solidarity, tolerance, responsibility, respect for life $e^{31}$. Lista ta okazała się wyjściowa i otwarta, jako że później została uzupełniona o następujące: security, dignity, diversity, participation/inclusion, environment, privacy, property ${ }^{32}$. Co więcej, każdy z autorów został zachęcony do uwzględnienia jeszcze innych wartości ważnych w jego jurysdykcji, które nie znalazły się na oryginalnej liście ${ }^{33}$.

$28 \mathrm{Na}$ temat szacunku dla tożsamości narodowych państw członkowskich Unii Europejskiej zob. B. Guastaferro, Sincere Cooperation and Respect for National Identities, [w:] Oxford Principles of European Union Law, t. 1. The European Union Legal Order, red. R. Schütze, T. Tridimas, Oxford 2018, s. 350 n.

29 D. Davis, A. Richter, C. Saunders, op. cit., s. 14.

30 Miłość jako wartość została wyeksponowana przez E. Skorczyńską w monumentalnej pracy Luka w prawie. Istota zjawiska oraz jego znaczenie dla prawa administracyjnego, Warszawa 2017. Autorka w końcowym fragmencie zatytułowanym Filozofia stosowania niepewnego prawa napisała: „Można [...] twierdzić — i jest to podstawowym wnioskiem płynącym z niniejszej pracy, że najsilniejszą wartością prawa, której oddziaływanie pozornie wydaje się nikłe, niewielkie, a nawet żadne, a które jednak w zupełności uzasadnia i »legalizuje« każde działanie w przestrzeni luki jest [...] miłość", ibidem, s. 486.

31 D. Davis, A. Richter, C. Saunders, op. cit., s. 11.

32 Ibidem.

33 Stąd może Y. Hasebe w rozdziale poświęconym Japonii wymienia w pewnym kontekście dążenie do szczęścia zagwarantowanie w art. 13 Konstytucji Japonii: „All of the people shall be respected as individuals. Their right to life, liberty, and the pursuit of happiness shall, to the extent 


\section{BADANIA PRAGMATYCZNE W EUROPEJSKIEJ PRZESTRZENI ADMINISTRACYJNO-PRAWNEJ}

Przykładem pragmatycznych komparatystycznych badań w europejskiej przestrzeni prawnej są badania nad procedurami administracyjnymi Unii Europejskiej prowadzone przez Sieć Badawczą Prawa Administracyjnego Unii Europejskiej (Research Network on European Union Administrative Law, ReNEUAL), która została założona w Osnabrück w czerwcu 2009 roku $^{34}$. Efektem tych prac jest model kodeksu postępowania administracji Unii Europejskiej (ReNEUAL model rules on European Union administrative procedure) ${ }^{35}$. Termin „model ReNEUAL" podkreśla akademicki charakter przedsięwzięcia, chociaż zasady i reguły modelu są sformułowane w sposób ułatwiający ich ewentualne wykorzystanie w formie rozporządzenia Parlamentu Europejskiego i Rady ${ }^{36}$. Model ReNEUAL jest częścią europejskiego prawa administracyjnego sensu stricto w znaczeniu prawa odnoszącego się do administracji UE. Mimo znaczącego rozwoju tego prawa w dwóch ostatnich dekadach ciągle nie jest ono tak rozwinięte jak krajowe prawo administracyjne i model ReNEUAL był bardzo inspirowany istniejącymi kodyfikacjami krajowymi. Z drugiej strony, model ten, uwzględniający doświad-

that it does not interfere with the public welfare, be the supreme consideration in legislation and in other governmental affairs"; idem, Japan, [w:] An Inquiry into the Existence of Global Values, s. 104.

$34 \mathrm{Na}$ temat początków i rozwoju Sieci zob. M. Wierzbowski, A. Kraczkowski, Powstanie modelu kodeksu postepowania administracyjnego Unii Europejskiej i jego wpływ na legislację europejska, [w:] Kodeks postępowania administracji Unii Europejskiej, red. J. Supernat, B. Kowalczyk, Warszawa 2017, s. 23 n., a także http://www.reneual.eu/. M. Wierzbowski i A. Kraczkowski wskazują, że: ,[i]nspiracją dla rozpoczęcia prac [...] nad modelem przepisów o postępowaniu administracyjnym były istniejące w Stanach Zjednoczonych modelowe przepisy stanowe zwane Restatements oraz prace cywilistów zmierzające do stworzenia europejskich przepisów w obszarze prawa cywilnego [...]", ibidem, s. 23. Na temat restatements zob. J. Supernat, Restatements - koncepcja i zastosowanie, [w:] Administracja publiczna pod rzadami prawa, s. $455 \mathrm{n}$.

35 Inny przykład pragmatycznych komparatystycznych badań w europejskiej przestrzeni prawnej zawiera praca M. Olczyk, Towards European Succesion Law. Draft Model Rules with Commenta$r y$, t. 3. Administration, partitioning and alienation of inheritance, Warszawa 2014. Praca M. Olczyk jest efektem udziału autorki w latach 2009-2010 w projekcie badawczym The perspectives of the Europeanization of the law of succession, którego celem było opracowanie modelowych zasad i reguł europejskiego prawa spadkowego z wykorzystaniem tradycji różnych krajowych systemów prawnych, w tym: czeskiego, litewskiego, łotewskiego, polskiego, słowackiego i węgierskiego. W pracy Towards European Succesion Law, która zawiera przedmiotowe zasady i reguły, autorka wyjaśnia i komentuje te dotyczące zarządu mieniem spadkowym, działem spadku i odrzuceniem spadku. Czyni to w sposób systematyczny, korzystając ze stałej struktury: geneza (national notes), rozwój (development), wyjaśnienie (explanation), kontekst (context) i przykłady (examples).

36 Tekst modelu ReNEUAL ma już kilka wersji językowych: angielską, francuską, hiszpańską, niemiecką, rumuńską, włoską i polską. Tekst w języku polskim został opublikowany przez C.H. Beck: ReNEUAL. Model kodeksu postępowania administracyjnego Unii Europejskiej, red. M. Wierzbowski et al., przeł. M. Ziental, P. Drobek, Warszawa 2015. Tekst angielski ma dwie wersje, a poprawiona druga została wydana przez Oxford University Press: ReNEUAL Model Rules on EU Administrative Procedure, red. P. Craig et al., Oxford 2017. 
czenia europejskie może znacząco wzbogacić krajowe procedury administracyjne $\mathrm{i}$ to nawet te o długiej i wpływowej tradycji. Taka cyrkulacja idei i koncepcji w europejskiej przestrzeni prawnej i administracyjnej jest niewątpliwie szalenie interesująca i pouczająca. Model ReNUAL składa się z sześciu ksiąg poświęconych przepisom ogólnym (księga I), wydawaniu przepisów przez organy administracji (księga II), wydawaniu decyzji w sprawach indywidualnych (księga III), umowom (księga IV), wzajemnej pomocy (księga V) i administracyjnemu zarządzaniu informacjami (księga VI). Dalszą uwagę skupimy na księdze III, dotyczącej ciągle podstawowej formy działania administracji, czyli decyzji w sprawach indywidualnych $^{37}$.

Księga III została przygotowana przez grupę roboczą składającą się z sześciu akademików pochodzących z pięciu krajów o różnych tradycjach prawnych: Hiszpanii (Oriol Mir), Niemiec (Jens-Peter Schneider i Vanessa M. Tunsmeyer), Polski (Marek Wierzbowski), Włoch (Giacinto della Cananea) i Zjednoczonego Królestwa (Paul Craig). Mimo że zgoda w kwestii koncepcji i konkretnych rozwiązań księgi III została osiągnięta z zadziwiającą łatwością (surprisingly easy) ${ }^{38}$, co wskazuje na uzyskanie znacznego stopnia konwergencji odnośnie do procedury administracyjnej w europejskiej przestrzeni prawnej i administracyjnej. Nie ma także fundamentalnych różnic odnośnie do zasad proceduralnych w księdze III i w prawie Zjednoczonego Królestwa, co sprawia, że nieuniknione różnice proceduralne w kwestiach szczegółowych nie rodzą jakichś szczególnych trudności i mogą zostać przezwyciężone ${ }^{39}$. W efekcie nie powinno być trudności ze zrozumieniem koncepcji księgi III w poszczególnych państwach członkowskich UE. Notabene oksfordzkie wydanie modelu ReNEUAL rozpoczyna porównawczy tekst poświęcony historycznemu uzasadnieniu, konstytutywnym cechom i recepcji kodeksów postępowania administracyjnego w pięciu krajach: Francji, Hiszpanii, Niemczech, Polsce i Włoszech ${ }^{40}$.

37 Zob. K. Ziemski, Indywidualny akt administracyjny - jego istota, [w:] System Prawa Administracyjnego, t. 5. Prawne formy działania administracji, red. R. Hauser, Z. Niewiadomski, A. Wróbel, Warszawa 2013, s. 151 n. W pierwszym akapicie opracowania autor wskazuje, że akt administracyjny indywidualny, będąc formą działania „typową dla administracji” i ,właściwą wyłącznie dla podmiotów wykonujących administrację publiczną” stał się ,,przedmiotem zainteresowań przedstawicieli nauki prawa administracyjnego w licznych opracowaniach i to od okresu międzywojennego", ibidem, s. 151. Przegląd poglądów doktryny Ziemski rozpoczyna od pracy K.W. Kumanieckiego, Akt administracyjny: studya nad istota aktu administracyjnego z uwzględnieniem zasadniczego orzecznictwa austryackiego trybunału administracyjnego, Kraków 1913.

38 Tak O. Mir, The Book III of the ReNEUAL Model Rules from Spanish Perspective, [w:] The Model Rules on EU Administrative Procedures: Adjudication, red. M. Ruffert, Groningen 2016, s. 75.

39 Zob. P. Craig, Unilateral Single Case Decisions: A UK Perspective, [w:] The Model Rules on EU Administrative Procedures, s. 43.

40 Zob. P. Craig et al., Administrative Procedure Acts: History, Features, and Reception, [w:] ReNEUAL Model Rules on EU Administrative Procedure, s. 1 n. Przy okazji: Zjednoczone Królestwo jest przykładem kraju, w którym procedura zawsze była uważana za istotną, a mimo to nie ma ogólnego kodeksu postępowania administracyjnego. Drugim takim krajem była do niedawna Francja, 
Termin „decyzja w sprawie indywidualnej” (a single case decision; an individual single case decision; an unilateral single case decision; an individual decision) dobrze odzwierciedla ten rodzaj działania administracji, który wiązany jest $\mathrm{w}$ tradycji niemieckiej i francuskiej z pojęciem jednostronnego aktu administracyjnego indywidualnego (unilateral individual administrative act). Akt administracyjny w tych państwach tworzy, wprawdzie z istotnymi różnicami, strukturę koncepcyjną, którą rządzą zasady legalności, proporcjonalności i bezpieczeństwa prawnego. Pojęcie decyzji w sprawie indywidualnej modelu ReNEUAL jest niewątpliwie częścią takiej struktury koncepcyjnej. Wypada jednak zauważyć, że w krajach common law główne cechy decyzji w sprawie indywidualnej nie rozwinęły się w związku koncepcją aktu administracyjnego, lecz koncepcją procesu podejmowania decyzji (decision making process) w powiązaniu ze sprawiedliwością naturalną (natural justice) i sprawiedliwością proceduralną (procedural fairness). $Z$ tego powodu termin „decyzja w sprawie indywidualnej” nie może być uważany za termin powszechnie znany w całej Europie jako nazwa powszechnie znanej koncepcji. Rzecz jasna, nie przekreśla to wykorzystania w modelu ReNEUAL różnych odrębnych elementów koncepcyjnych wiązanych z decyzją w sprawie indywidualnej w krajowych porządkach prawnych. Można je identyfikować między innymi w czterech tradycjach prawa administracyjnego w Europie: tradycji zorientowanej na administrację, tradycji zorientowanej na jednostkę, tradycji zorientowanej na legislatora i tradycji zorientowanej na ombudsmana ${ }^{41}$. Przy czym czerpanie inspiracji z różnych tradycji i krajowych porządków prawnych nie może przesłaniać głównego celu modelu ReNEUAL, którym jest opracowanie sposobów (procedur) poprawy implementacji prawa UE i zatem musi odpowiadać specjalnemu charakterowi i specyficznym potrzebom tej implementacji. Notabene we wprowadzeniu do modelu ReNEUAL w punkcie 11 znajduje się następujące jednoznaczne stwierdzenie: „Przepisy dotyczące postępowania administracyjnego muszą być tak skonstruowane, aby w równym stopniu maksymalizować bliźniacze cele prawa publicznego (to equally maximze the twin objectives of public law): zapewnić, że przedmiotowe instrumenty wspierają efektywne wykonywanie obowiązków publicznych, a jednocześnie zapewnić ochronę praw jednostek". Postępowanie

ale 1 stycznia 2016 r. wszedł tam w życie kodeks postępowania administracyjnego o nazwie: Code des relations entr le public et l'administration (Code of the relations between the public and public administration), czyli Kodeks stosunków między społeczeństwem i administracją publiczną, za czym przemówiły argumenty zrozumiałości i przyjazności dla członków społeczeństwa. W nazwie tego kodeksu nie ma terminu ,procedura administracyjna” (procedure administrative), ponieważ we Francji termin ten tradycyjnie wymaga dalszego dookreślenia w postaci terminu ,niesporna” (non-contentieus), aby uniknąc konfuzji z procedurą sądowoadministracyjną, a termin „kodeks procedury administracyjnej niespornej” byłby dla zdecydowanej większości społeczeństwa niezrozumiały i nieprzyjazny.

41 Zob. The Swedish Statskontoret, Principles of Good Administration in the Member States of the European Union, 2005, s. 74. 
administracyjne nie może być zatem postrzegane jako „gra” o sumie zerowej (a zero-sum game), w której wygranej jednej strony odpowiada strata drugiej.

Podejmowanie decyzji w sprawach indywidualnych jest rdzeniem większości kodyfikacji administracyjnego prawa proceduralnego i zatem nie dziwi, że właśnie księga III modelu ReNEUAL stała się punktem wyjścia prób stworzenia na poziomie UE proceduralnego prawa administracyjnego opartego na rządach prawa. Najnowszą taką próbą jest projekt rozporządzenia Parlamentu Europejskiego i Rady w sprawie otwartej, efektywnej i niezależnej administracji Unii Europejskiej stanowiącego załącznik do rezolucji Parlamentu Europejskiego z dnia 9 czerwca 2016 roku w sprawie otwartej, efektywnej i niezależnej administracji Unii Europejskiej ${ }^{42}$. Tożsamość czy tylko podobieństwo rozwiązań w księdze III modelu ReNEUAL i projekcie rozporządzenia jest bardzo widoczna ${ }^{43}$.

\section{KOMPARATYSTYKA PRAWNICZA NOMINALNA}

Zdarzają się w doktrynie prace, które są pracami prawnoporównawczymi tylko nominalnie. Należy do nich praca Samorzad terytorialny w Polsce i Portugalii. Analiza prawnoporównawcza. Local government in Poland and Portugal. Comparative legal analysis ${ }^{44}$. Jej treść nie odpowiada tytułowi (jego drugiej części), a także temu, co pisze B. Dolnicki we Wstępie: „Opracowanie jest pierwszą publikacją naukową zawierającą jednocześnie analizę polskiego i portugalskiego ustroju samorządu terytorialnego oraz porównanie tych dwóch systemów administracji publicznej" ${ }^{45}$. Wskazana praca w żadnym fragmencie nie zawiera analizy prawnoporównawczej i zatem nie jest pracą prawnoporównawczą. Jest natomiast

42 2016/2610 (RSP). Podkreślić należy, że celem projektowanego rozporządzenia jest przyjęcie reguł proceduralnych służących zagwarantowaniu — jak mówi tytuł dokumentu — „otwartej, efektywnej i niezależnej administracji Unii Europejskiej”, ale także właściwą egzekucję prawa do dobrej administracji, o czym wyraźnie mówi punkt 14 wprowadzenia: „The purpose of this Regulation is to establish a set of procedural rules which the Union's administration should comply with when carrying out its administrative activities. These procedural rules aim at assuring both an open, efficient and independent administration and a proper enforcement of the right to good administration". Przepis art. 1 ust. 2 ujmuje ten podwójny cel jeszcze nieco inaczej, dając pierwszeństwo prawu do dobrej administracji i widząc w otwartej, efektywnej i niezależnej administracji UE środek realizacji tego prawa: „The objective of this Regulation is to guarantee the right to good administration enshrined in Article 41 of the Charter of Fundamental Rights of the European Union by means of an open, efficient and independent administration".

43 Zob. B. Adamiak, Decyzja w modelu kodeksu postępowania administracyjnego Unii Europejskiej sieci ReNEUAL $i$ w projekcie rozporzadzenia Parlamentu Europejskiego i Rady w sprawie postępowania administracyjnego instytucji, organów i jednostek organizacyjnych Unii Europejskiej, [w:] Kodeks postępowania administracji Unii Europejskiej, s. 207 n.

44 Samorzad terytorialny w Polsce i Portugalii. Analiza prawnoporównawcza. Local government in Poland and Portugal. Comparative legal analysis, red. B. Dolnicki, Warszawa 2015.

45 B. Dolnicki, Wstęp, [w:] Samorząd terytorialny w Polsce i Portugalii, s. 7. 
pracą zawierającą studia o samorządzie terytorialnym w dwóch krajach: w Polsce autorstwa polskich autorów i — z nieujawnionych przesłanek ${ }^{46}-\mathrm{w}$ Portugalii autorstwa portugalskich autorów ${ }^{47}$. Prac tego typu jest wiele, a wśród nich książka o gminie w ośmiu państwach zachodnich: Samorząd terytorialny $i$ administracja $w$ wybranych krajach. Gmina w państwach Europy Zachodniej ${ }^{48}$, której redaktor napisał jednoznacznie: ,Jest to zbiór studiów o sytuacji prawnoustrojowej gminy w państwach zachodnich; nie jest jednak pracą z zakresu badań porównawczych, w myśl przyjmowanych założeń metodologicznych. Może być jednak punktem wyjścia i stanowić solidną podstawę do prowadzenia takich badań"49. Innymi słowy, samo opisanie zagranicznych krajowych rozwiązań prawnych jako takich nie jest jeszcze analizą prawnoporównawczą. Może natomiast stanowić pierwszy krok na drodze do dokonania takiej analizy. Tyle też można powiedzieć o pracy pod redakcją B. Dolnickiego.

Wskazana praca ma oczywiście niewątpliwe zalety. Czytelnik otrzymuje z pierwszej ręki rzetelny opis systemu samorządu terytorialnego w Polsce i Portugalii. Wersja angielska jest jej dodatkowym walorem i sprawia, że jest ona użyteczna w dzisiejszym procesie dydaktycznym z coraz szerszym udziałem studentów zagranicznych i zajęć prowadzonych w języku angielskim. Dostarcza ponadto materiału (informacji), pozwalającego czytelnikowi porównać system samorządu terytorialnego w Polsce i Portugalii ${ }^{50}$. Sami autorzy takiego porównania jednak

46 Wybór krajów do badania porównawczego może wynikać z celu porównania, własnych badań wstępnych, dostępności informacji, znajomości języków obcych, wcześniejszych badań porównawczych innych autorów itp. Ważna jest przy tym liczba krajów wybranych do zbadania. Wybór tylko dwóch krajów, w tym jednego własnego, co zresztą jest dość popularne, nie wydaje się szczególnie obiecujący. Istotne w takim przypadku jest znaczne przestrzenne oddalenie badanych krajów (notabene jest tak w przypadku Polski i Portugalii) i przypuszczalnie związane z tym duże różnice między rozwiązaniami przyjętymi w wybranych państwach, co może być źródłem między innymi oryginalnych wniosków de lege ferenda.

47 Studia o polskim i portugalskim samorządzie terytorialnym zostały przedłożone w dwóch językach, polskim i angielskim. Uwaga ta jest istotna, jako że w ogólnym przypadku posłużenie się obcym językiem do opisania rozwiązań prawnych w danym kraju może oznaczać zaangażowanie się w badania porównawcze: użycie pewnych słów, a nie innych dla przetłumaczenia określonych pojęć, rozwiązań i idei przyniesie inną wiadomość prawną czytelnikowi. Rzecz jasna, konieczna jest tutaj kompetencja językowa i samodzielne pisanie w obcym języku, a nie korzystanie z usług zawodowych tłumaczy, którzy często nie znają systemów prawnych (w konkretnym przypadku polskiego i portugalskiego). Notabene, ponieważ dobre rozumienie zagranicznych rozwiązań prawnych wymaga dobrych narzędzi translatorskich (słowników itp.), opracowanie takowych może być traktowane jako jeden z (bliższych, wstępnych) celów badań prawnoporównawczych.

48 Samorzad terytorialny $i$ administracja w wybranych krajach. Gmina w państwach Europy Zachodniej, red. J. Jeżewski, Wrocław 1999.

49 J. Jeżewski, Od Redaktora, [w:] Samorząd terytorialny i administracja w wybranych krajach, s. 12.

50 Dokonaniu porównania nie sprzyja jednak asymetria strukturalna między częścią polską i portugalską (a podkreślić należy, że struktura opisu rozwiązań prawnych przeznaczonych do porównania jest krytyczna dla powodzenia badań porównawczych i powinna zwłaszcza spełniać wymóg 
nie dokonują, a poszczególne rozdziały są czysto krajowe. A przecież „charakter prawnoporównawczy" pracy mógł zagwarantować na przykład odrębny ostatni rozdział czy choćby rozszerzone zakończenie ${ }^{51}$, z identyfikacją i analizą podobieństw i różnic w opisywanych wybranych elementach samorządu terytorialnego w Polsce i Portugalii, a także ze wskazaniem, jak poszczególne systemy prawne podchodzą do tych samych kwestii, odpowiednio do przyjętego celu porównania ${ }^{52}$. W ten sposób zostałaby zrealizowana tytułowa zapowiedź, czyli dokonanie analizy prawnoporównawczej samorządu terytorialnego w Polsce i Portugalii.

Jeżeli chodzi o treść przedmiotowej książki, to nie można nie odnieść się do przekonania B. Dolnickiego, że

[w]śród omawianych tematów znalazły się [...] kwestie, które dotychczas nie były przedmiotem zainteresowania doktryny, a mogące stanowić przyczynek do wzajemnej wymiany doświadczeń w zakresie szeroko rozumianej praktyki samorządu terytorialnego. Tytułem przykładu wskazać można na przeanalizowaną w monografii problematykę konstytucyjnego usytuowania polskiego i portugalskiego samorządu terytorialnego w ustroju państwowym, rolę, znaczenie i zadania lokalnych oraz regionalnych jednostek samorządu terytorialnego, a także pozycję organów tych jednostek ${ }^{53}$.

Otóż wszystkie te kwestie były przedmiotem zainteresowania doktryny, zwłaszcza J. Korczaka ${ }^{54}$ i samego B. Dolnickiego, co zresztą tenże w odniesieniu do „miejsca samorządu terytorialnego w polskich konstytucjach” wyraźnie zaznacza: „Pisałem na ten temat B. Dolnicki, Samorząd terytorialny, wyd. 5, Warsza-

egzogenności, unikając niebezpieczeństwa etnocentryzmu), znajdująca notabene odbicie w asymetrii ilościowej: część polska (w obu wersjach językowych) liczy 346 stron i jest ponaddwukrotnie większa od portugalskiej, która ma (w obu wersjach językowych) 166 stron. Dla dokonania analizy prawnoporównawczej nieoceniony byłby także skorowidz rzeczowy, którego nie ma. Można też było zadbać o porównanie pojęciowe i jednolitość terminologiczną wersji angielskich. Na przykład dla polskich autorów gmina to commune, a dla portugalskich — municipality. Jest też ciekawe, jak powstała wersja polska w części portugalskiej: czy jest tłumaczeniem z języka angielskiego, czy może jednak z języka oryginalnego, co byłoby trudniejsze i zatem wydaje się mniej prawdopodobne.

51 W pracy zakończenia w ogóle nie ma, a jej ostatni akapit, kończący się notabene odnośnikiem, nie ma głębi, horyzontu i perspektywy, będąc spojrzeniem na konkret: „W powyższych sprawach zabezpieczenie karne obejmuje kwestię prawną »uczciwości w sprawowaniu urzędu publicznego « (zgodnie z systematycznym odniesieniem w rozdziale dotyczącym przestępstw popełnianych w trakcie sprawowania urzędu publicznego) oraz wartości konstytucyjne dotyczące ochrony w planowaniu przestrzennym i racjonalnej, zrównoważonej gospodarki gruntami”, J. Caupers et al., Portugalia, [w:] Samorzad terytorialny w Polsce i Portugalii, s. 527.

52 Najnowszy przykład połączenia opisu wybranych systemów krajowych i analizy prawnoporównawczej zawiera praca The Max Planck Handbooks in European Public Law, t. 1. The Administrative State, red. A. von Bogdandy, P.M. Huber, S. Cassese, Oxford 2017.

53 B. Dolnicki, Wstęp, s. 7.

54 Zob. J. Korczak, Konstytucyjne podstawy struktury i funkcji samorzadu terytorialnego, [w:] System Prawa Administracyjnego, t. 2. Konstytucyjne podstawy funkcjonowania administracji publicznej, red. R. Hauser, Z. Niewiadomski, A. Wróbel, Warszawa 2012, s. 151 n. To obszerne studium wybitnego znawcy teorii i praktyki samorządu terytorialnego nie zostało dostrzeżone w przedmiotowej pracy. 
wa 2012, rozdział 3"55. Potwierdza się, że pamięć jest zawodna. Rozwiązaniem mogłoby być skorzystanie z pamięci zewnętrznej w postaci pamięci recenzenta. W tym przypadku tak się jednak stać nie mogło, jako że praca Samorzad terytorialny w Polsce i Portugalii. Analiza prawnoporównawcza. Local government in Poland and Portugal. Comparative legal analysis nie jest książką recenzowaną, a przynajmniej recenzent nie został w niej wskazany.

$* * *$

Komparatystyka prawnicza od zawsze jest istotna w stanowieniu i stosowaniu prawa (w tym poszukiwaniu rozwiązań de lege ferenda), ale w sytuacji kształtowania się globalnych, międzynarodowych i ponadpaństwowych przestrzeni prawnych (w tym przez harmonizację i unifikację $e^{56}$ ) jest w doktrynie i praktyce prawniczej niezastąpiona. Prawo w tych przestrzeniach często jest następstwem kompromisu między różnymi kulturami prawnymi oraz uznania (prakseologicznej i/lub aksjologicznej) hegemonii jednej z nich (co notabene pozwala mówić o kulturach i systemach prawnych eksportujących i importujących), a jego stosowanie wymaga znajomości na przykład ogólnych zasad prawa ${ }^{57}$. W tych okolicznościach potrzeba poznania klasycznych i nowych obszarów i metod stosowania komparatystyki prawniczej, a także eliminowania niezrozumienia (i turystycznego spojrzenia na inny system prawny), jakie tutaj się pojawia, jest oczywiste. I właśnie wybranym zagadnieniem z tego zakresu zostało poświęcone powyższe opracowanie.

\section{LEGAL COMPARATISTICS. SELECTED ISSUES}

\section{Summary}

Legal comparatistics has always been critically important for passing and applying the law, but in emerging supranational spaces is indispensable. Under these circumstances the text discusses four chosen issues: studying law and reflections on it, looking for similarities and differences, pragmatic research in the European administrative-legal space and nominal legal comparatistics.

Keywords: comparatistics, law, legal comparatistics

55 B. Dolnicki, Miejsce samorzadu terytorialnego w polskich konstytucjach, [w:] Samorzad terytorialny $w$ Polsce i Portugalii, s. 41.

56 Miękkim (soft) sposobem unifikacji prawa jest opracowany przez ReNEUAL model kodeksu postępowania administracji Unii Europejskiej, o którym traktuje punkt 3 tego opracowania.

57 Można tutaj przytoczyć przepis art. 340 ust. 2 Traktatu o funkcjonowaniu Unii Europejskiej, mówiący o „zasadach ogólnych wspólnych dla praw państw członkowskich”: „W dziedzinie odpowiedzialności pozaumownej Unia powinna naprawić, zgodnie z zasadami ogólnymi, wspólnymi dla praw państw członkowskich, szkody wyrządzone przez jej instytucje lub jej pracowników przy wykonywaniu ich funkcji”. Obszernie i porównawczo na temat zasad prawa Unii Europejskiej zob. Oxford Principles of European Union Law, t. 1, passim. 


\section{BIBLIOGRAFIA}

Adamiak B., Decyzja w modelu kodeksu postepowania administracyjnego Unii Europejskiej sieci ReNEUAL i w projekcie rozporzadzenia Parlamentu Europejskiego i Rady w sprawie postepowania administracyjnego instytucji, organów i jednostek organizacyjnych Unii Europejskiej, [w:] Kodeks postępowania administracji Unii Europejskiej, red. J. Supernat, B. Kowalczyk, Warszawa 2017.

Bauer M.W., Trondal J., The Administrative System of the European Union, [w:] The Palgrave Handbook of the European Administrative System, red. M.W. Bauer, J. Trondal, Basingstoke 2015.

Brodecki Z., Metodologia regulae iuris, [w:] Z. Brodecki, M. Konopacka, A. Brodecka-Chamera, Komparatystyka kultur prawnych, Warszawa 2010.

Caupers J., Moniz A.R., Fonseca I.C., de Seves A.L., Portugalia, [w:] Samorząd terytorialny w Polsce i Portugalii. Analiza prawnoporównawcza. Local government in Poland and Portugal. Comparative legal analysis, red. B. Dolnicki, Warszawa 2015.

Comparative Law in the 21st Century, red. A. Harding, E. Örücü, London 2002.

Craig P., Unilateral Single Case Decisions: A UK Perspective, [w:] The Model Rules on EU Administrative Procedures: Adjudication, red. M. Ruffert, Groningen 2016.

Craig P., Cananea G. della, Galetta D.-U., Mir O., Schneider J.-P., Stelkens U., Wierzbowski M., Ziller J., Administrative Procedure Acts: History, Features, and Reception, [w:] ReNEUAL Model Rules on EU Administrative Procedure, red. P. Craig, H.C.H. Hofmann. J.-P. Schneider, J. Ziller, Oxford 2017.

Davis D., Richter A., Saunders C., Introduction, [w:] An Inquiry into the Existence of Global Values. Through the Lens of Comparative Constitutional Law, red. D. Davis, A. Richter, C. Saunders, Oxford 2015.

Dolnicki B., Miejsce samorzadu terytorialnego w polskich konstytucjach, [w:] Samorzad terytorialny w Polsce i Portugalii. Analiza prawnoporównawcza. Local government in Poland and Portugal. Comparative legal analysis, red. B. Dolnicki, Warszawa 2015.

Dolnicki B., Wstę, [w:] Samorzad terytorialny w Polsce i Portugalii. Analiza prawnoporównawcza. Local government in Poland and Portugal. Comparative legal analysis, red. B. Dolnicki, Warszawa 2015.

Glenn H.P., Legal Traditions of the World. Sustainable Diversity in Law, Oxford 2010.

Guastaferro B., Sincere Cooperation and Respect for National Identities, [w:] Oxford Principles of European Union Law, t. 1. The European Union Legal Order, red. R. Schütze, T. Tridimas, Oxford 2018.

Hasebe Y., Japan, [w:] An Inquiry into the Existence of Global Values. Through the Lens of Comparative Constitutional Law, red. D. Davis, A. Richter, C. Saunders, Oxford 2015.

Jeżewski J., Administracja publiczna jako przedmiot badań, [w:] A. Błaś, J. Boć (red.), J. Jeżewski, Nauka administracji, Wrocław 2013.

Jeżewski J., Franciszek Longchamps de Berier (1912-1969), [w:] Pamięci zmartych Profesorów i Docentów Wydziału Prawa, Administracji i Ekonomii Uniwersytetu Wrocławskiego 19452010, red. L. Lehmann, M. Maciejewski, Wrocław 2010.

Jeżewski J., Od Redaktora, [w:] Samorząd terytorialny i administracja w wybranych krajach. Gmina w państwach Europy Zachodniej, red. J. Jeżewski, Wrocław 1999.

Kieres L., Europejska Karta Samorzadu Terytorialnego w orzecznictwie Trybunału Konstytucyjnego, „Ruch Prawniczy, Ekonomiczny i Socjologiczny” 2015, nr 3.

Kieres L., Sprawna administracja w orzecznictwie Trybunatu Konstytucyjnego, [w:] Administracja publiczna pod rzadami prawa. Ksiega pamiatkowa z okazji 70-lecia urodzin prof. zw. dra hab. Adama Btasia, red. J. Korczak, Wrocław 2016.

Korczak J., Konstytucyjne podstawy struktury i funkcji samorzadu terytorialnego, [w:] System Prawa Administracyjnego, t. 2. Konstytucyjne podstawy funkcjonowania administracji publicznej, red. R. Hauser, Z. Niewiadomski, A. Wróbel, Warszawa 2012.

Przegląd Prawa i Administracji 114, 2018

(C) for this edition by CNS 
Kumaniecki K.W., Akt administracyjny: studya nad istota aktu administracyjnego z uwzględnieniem zasadniczego orzecznictwa austryackiego trybunału administracyjnego, Kraków 1913.

Longchamps de Berier F., Współczesne kierunki w nauce prawa administracyjnego na Zachodzie Europy, Wrocław 2001.

The Max Planck Handbooks in European Public Law, t. 1. The Administrative State, red. A. von Bogdandy, P.M. Huber, S. Cassese, Oxford 2017.

The Migration of Constitutional Ideas, red. S. Choudhry, Cambridge 2006.

Mir O., The Book III of the ReNEUAL Model Rules from Spanish Perspective, [w:] The Model Rules on EU Administrative Procedures: Adjudication, red. M. Ruffert, Groningen 2016.

Olczyk M., Towards European Succesion Law. Draft Model Rules with Commentary, t. 3. Administration, partitioning and alienation of inheritance, Warszawa 2014.

Ongaro E., von Thiel S., Languages and Public Administration in Europe, [w:] The Palgrave Handbook of Public Administration and Management in Europe, t. 1, red. E. Ongaro, S. von Thiel, London 2018.

Oxford Principles of European Union Law, t. 1. The European Union Legal Order, red. R. Schütze, T. Tridimas, Oxford 2018.

Örücü E., Developing Comparative Law, [w:] Comparative Law. A Handbook, red. D. Nelken, E. Örücü, Portland 2007.

ReNEUAL. Model kodeksu postepowania administracyjnego Unii Europejskiej, red. M. Wierzbowski, A. Kraczkowski, Warszawa 2015.

ReNEUAL Model Rules on EU Administrative Procedure, red. P. Craig et al., Oxford 2017.

Samorzad terytorialny w Polsce i Portugalii. Analiza prawnoporównawcza. Local government in Poland and Portugal. Comparative legal analysis, red. B. Dolnicki, Warszawa 2015.

Skorczyńska E., Luka w prawie. Istota zjawiska oraz jego znaczenie dla prawa administracyjnego, Warszawa 2017.

Starościak J., Wprowadzenie do prawa administracyjnego europejskich państw socjalistycznych, Warszawa 1968.

Supernat J., Restatements - koncepcja i zastosowanie, [w:] Administracja publiczna pod rzadami prawa. Księga pamiątkowa z okazji 70-lecia urodzin prof. zw. dra hab. Adama Błasia, red. J. Korczak, Wrocław 2016.

Trondal J., Peters B.G., A Conceptual Account of the European Administrative Space, [w:] The Palgrave Handbook of the European Administrative System, red. M.W. Bauer, J. Trondal, Basingstoke 2015.

Wierzbowski M., Kraczkowski A., Powstanie modelu kodeksu postępowania administracyjnego Unii Europejskiej i jego wplyw na legislację europejska, [w:] Kodeks postępowania administracji Unii Europejskiej, red. J. Supernat, B. Kowalczyk, Warszawa 2017.

Ziemski K., Indywidualny akt administracyjny - jego istota, [w:] System Prawa Administracyjnego, t. 5. Prawne formy działania administracji, red. R. Hauser, Z. Niewiadomski, A. Wróbel, Warszawa 2013. 